\title{
Settlement and social organisation in the late fourth millennium BC in Central Europe: the waterlogged site of Zurich-Parkhaus Opéra
}

Niels Bleicher ${ }^{1, *} \&$ Christian Harb ${ }^{2}$

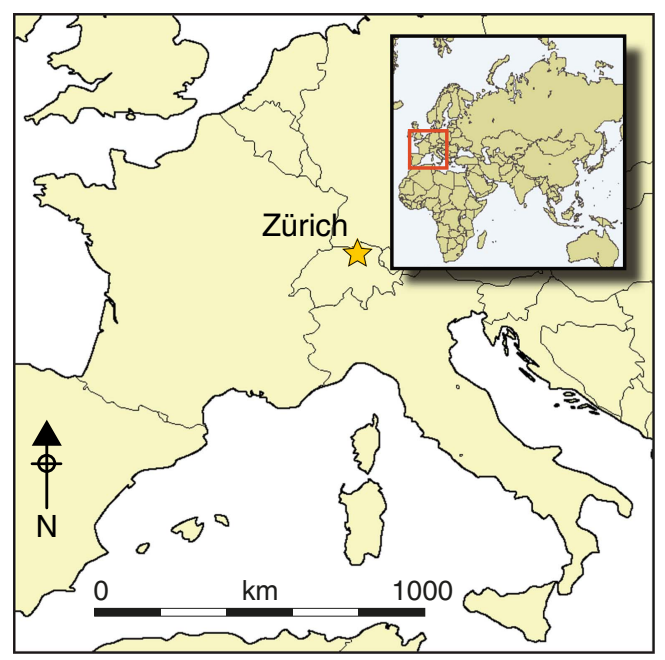

With the exception of Circum-Alpine wetland sites, structural remains of fourth-millennium $B C$ settlements in Central Europe are rarely encountered. As a result, there is a dearth of information concerning settlement organisation and social differentiation. Recent excavations at the waterlogged Parkhaus Opéra site on the shores of Lake Zurich have, however, provided important new evidence for the existence of complex Late Neolithic settlement strategies and social stratification. Excellent organic preservation conditions permit extensive dendrochronological analyses of structures and the precise phasing of building activity. The results reveal a complex and highly dynamic settlement system, and provide a rare insight into the organisation of Late Neolithic Central European society.

Keywords: Switzerland, Neolithic Alpine foreland, dendroarchaeology, settlement archaeology

\section{Introduction}

The waterlogged prehistoric sites of the Circum-Alpine region are well known for their high archaeological potential. In particular, the preservation of organic materials at these sites often allows for high-precision dendrochronological dating of structural remains.

1 Office for Urbanism, Underwater Archaeology and Laboratory for Dendrochronology, Seefeldstrasse 317, CH-8008 Zurich, Switzerland

2 Cantonal Archaeology Zurich, Stettbachstrasse 7, CH-8600 Dübendorf, Switzerland

* Author for correspondence (Email: niels.bleicher@zuerich.ch)

(C) Antiquity Publications Ltd, 2018. This is an Open Access article, distributed under the terms of the Creative Commons Attribution licence (http://creativecommons.org/licenses/by/4.0/), which permits unrestricted reuse, distribution and reproduction in any medium, provided the original work is properly cited.

ANTIQUITY, 92365 (2018): 1210-1230

https://doi.org/10.15184/aqy.2018.109 
This evidence is especially important due to the general scarcity of surviving fourthmillennium BC settlement remains from Central Europe.

The Circum-Alpine region encompasses Switzerland and parts of Austria, France, Germany, Slovenia and Italy. Here, the Neolithic societies were for decades considered to have been egalitarian in social status (Kaeser 2004). This view was based on archaeological evidence for the architectural similarity of houses, which were of comparable size, with few indicators of social inequality. Further, each house appears to have stored its own supply of cereals (with some variability in crop species), leading to the suggestion that the autonomous nuclear family was the basic social and economic unit at these sites, although communal building activities, such as palisade construction, suggest some form of village-scale organisation or authority (Hasenfratz \& Gross-Klee 1995: 228). Recently, however, this egalitarian interpretation has been challenged. Differences in archaeobiological economic data (e.g. animal bone and fish remains) for individual houses, for example, need not be taken to indicate household autonomy; for Arbon-Bleiche 3, on the shore of Lake Constance, Doppler et al. (2011: 153) suggest that these differences may rather hint at social units with complementary economic functions and focus, within an egalitarian framework.

Similarly, growing evidence that settlements were constantly reorganised-given that short-lived buildings were relocated and rebuilt—has led Ebersbach (2010) to question even the concept of the 'village'. Dendrochronological data from, for example, Hornstaad-Hörnle IA on the German shore of Lake Constance (Billamboz 2006), suggest that sometimes groups of buildings were moved simultaneously to form new settlements next to older ones, which persisted at a smaller scale. In other cases, buildings were erected in the locations of houses from earlier settlement phases. Ebersbach (2010) therefore has proposed the existence of social units that were intermediate in size between house (or household) and settlement. Drawing on general architectural and sociological studies by Hanson and Hillier (1987), Ebersbach has suggested that Neolithic settlement in the Circum-Alpine region could be described as a 'non-correspondence system'. This is an ethnographically documented concept, whereby an individual's identity as a member of a particular social group does not directly correspond with the immediate residence group, and where important needs are met outside the residence group. Genetic or spiritual relationships, for example, may be the most important social labels and frameworks of contact in a given society, but do not define who is living and eating together. Communities organised in such a way frequently show little social control over contacts being made among individuals. Their buildings and settlements are often relocated and reorganised; their individuals are mobile and maintain many external contacts beyond the settlement. In contrast, in communities organised as correspondence systems, residence groups correspond more closely to the relevant social labels. For example, if genetic relationships are among the most important social labels, then families live together. In such communities, there is a tendency towards pronounced regulation of social contacts, both physically in the form of boundaries, such as fences, and socially through rules and symbols. Such societies are characterised by greater local stability, as villages are less frequently relocated and reorganised (Ebersbach 2010: 150-52). More recent work by Hofmann et al. (2016) has also stressed the importance of analysing Neolithic settlement data across spatial scales from the house/household, through settlements, to entire landscapes and even over time. 
Excavations covering large contiguous areas - or even complete settlements-with wellpreserved organic deposits are rare. But it is only at such sites that it is possible to unlock the full potential of dendroarchaeology, and to identify the spatial and temporal organisation of settlements and the relationships between neighbouring settlements. Over recent decades, a number of waterlogged sites of the late fourth-millennium BC Horgen Culture have been excavated within the city of Zurich, and the remains dated dendrochronologically. The ideal preservation conditions at the Parkhaus Opéra site permit the evaluation of recent interpretations of social structure in the Neolithic Alpine foreland. Here, we introduce this exceptional site and consider the implications of its (dendro-)archaeological evidence for our understanding of Neolithic architecture and society. We discuss settlement phasing in order to reflect on wider understanding of settlement dynamics around Lake Zurich. We also critically re-evaluate the interpretation of (non-)correspondence as a driving model of Late Neolithic settlement organisation, and present the first results of an analysis of social differentiation.

\section{The Parkhaus Opéra site}

In 2010, a large-scale rescue excavation of a waterlogged Neolithic settlement was undertaken in advance of the construction of an underground car park in Zurich (Figure 1). An area of approximately $3000 \mathrm{~m}^{2}$ was excavated, exposing six settlement deposits with varying degrees of organic preservation. Two layers (13 and 14) contained large quantities of waterlogged organic material. Dendrochronological and radiocarbon dating revealed eight Late and Final Neolithic settlement phases between 3234 and 2727 BC (Figures 2 \& S6 (the latter in the online supplementary material (OSM)); Bleicher \& Burger 2015), from which many finds and samples were retrieved. More than 20000 piles and horizontal timbers were documented and analysed. Interdisciplinary research on the remains was initiated in 2012 (Bleicher \& Harb 2015, 2017; Harb \& Bleicher 2016).

\section{Methods}

Due to time constraints, it was impossible to excavate the full $3000 \mathrm{~m}^{2}$ of the site to a uniform standard. Three different excavation modes were therefore used to excavate at varied levels of speed and detail. These were intermixed across the whole site in order to recover comparable data and samples (Figure 3). Full details on the excavation methods and site taphonomy are published elsewhere (Bleicher \& Harb 2015: 15-17; Bleicher et al. 2018).

All the wooden piles were sampled, and details such as shape, size, wood species and number of tree rings were entered into a database; full details of the methods applied during dendrochronological and pile-field analyses are provided in the OSM, as are all raw data for the pile field. GIS mapping reveals rows or rectangular arrangements of piles with uniform properties; for example, a palisade of split alder posts and lines of closely spaced, thin round poplar piles (Figures 4 \& S3: structures NS7 and SW_NO_1), which represent buildings, pathways and enclosures. Once mapped, these structures were dated and organised into phases (see the OSM: S3, S4, S6).

(C) Antiquity Publications Ltd, 2018 


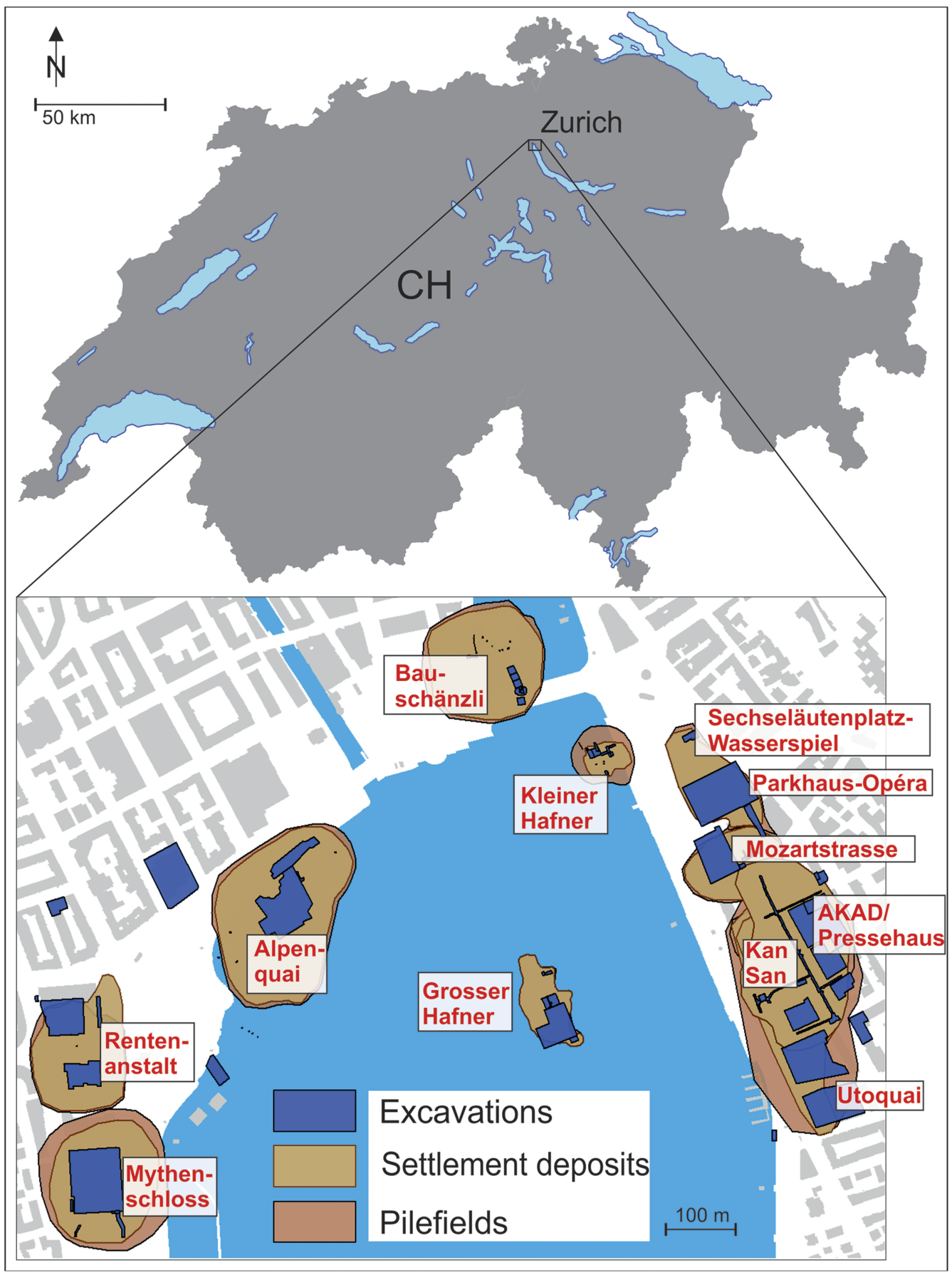

Figure 1. Top) map of the lower basin of Lake Zurich; bottom) location of prehistoric lakeside sites in and around Lake Zurich (figure by Niels Bleicher). 


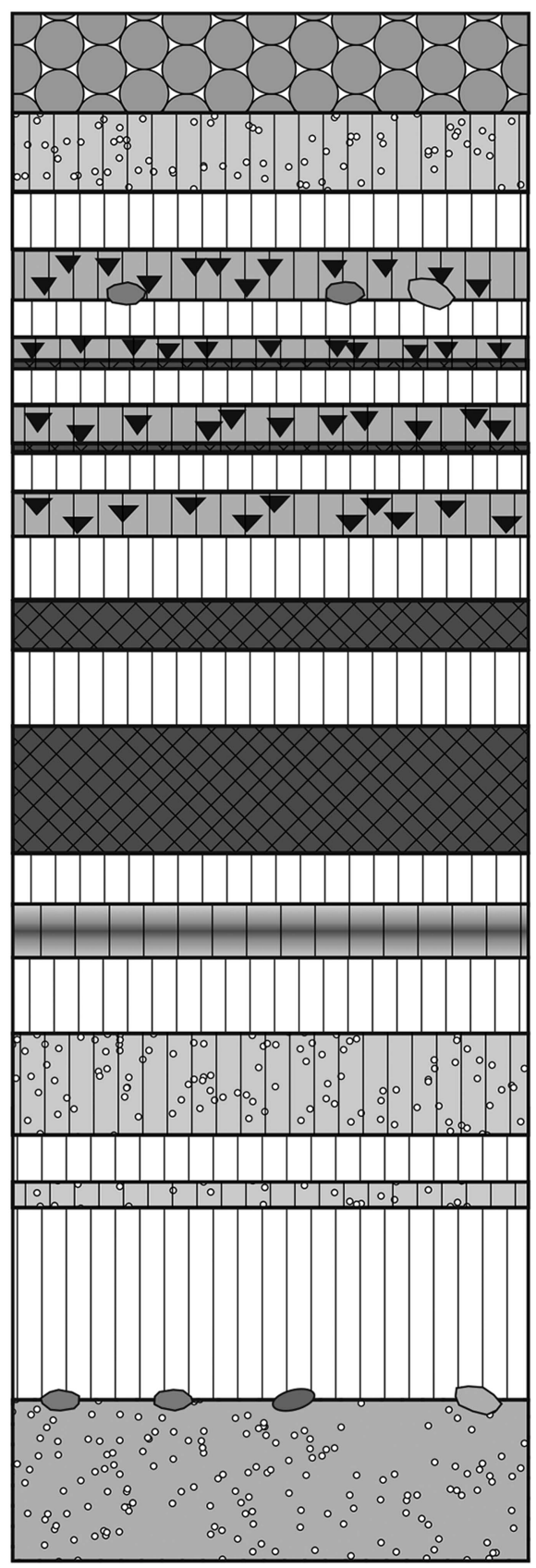

$\square$ Lake marl, white/grey 19th-century fill

Medieval and early modern sediments

Layer of erosion and reduction

Layer 17, phases 7 \& 8, 2754-2749 \& 2734-2727 BC

Layer 16, phase 6, 2885-2877 BC

Layer 15, phase 5, c. 3060 BC

Layer 14, phase 4, c. $3090 \mathrm{BC}$

Layer 13, phase 3, 3176-3153 BC

Layer 12, phase 1, 3234-3226 BC

Deposit of possible underwater landslide, male skeleton c. $3750 \mathrm{BC}$

Early Holocene sands

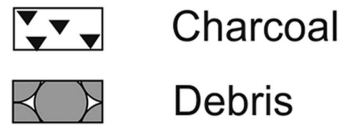
X Organically preserved deposits $\forall \gg$ Debris $0_{8 \circ}^{\circ}$ Sand/stones

Figure 2. Idealised stratigraphy of the Parkhaus Opéra site (figure by Niels Bleicher).

(C) Antiquity Publications Ltd, 2018 


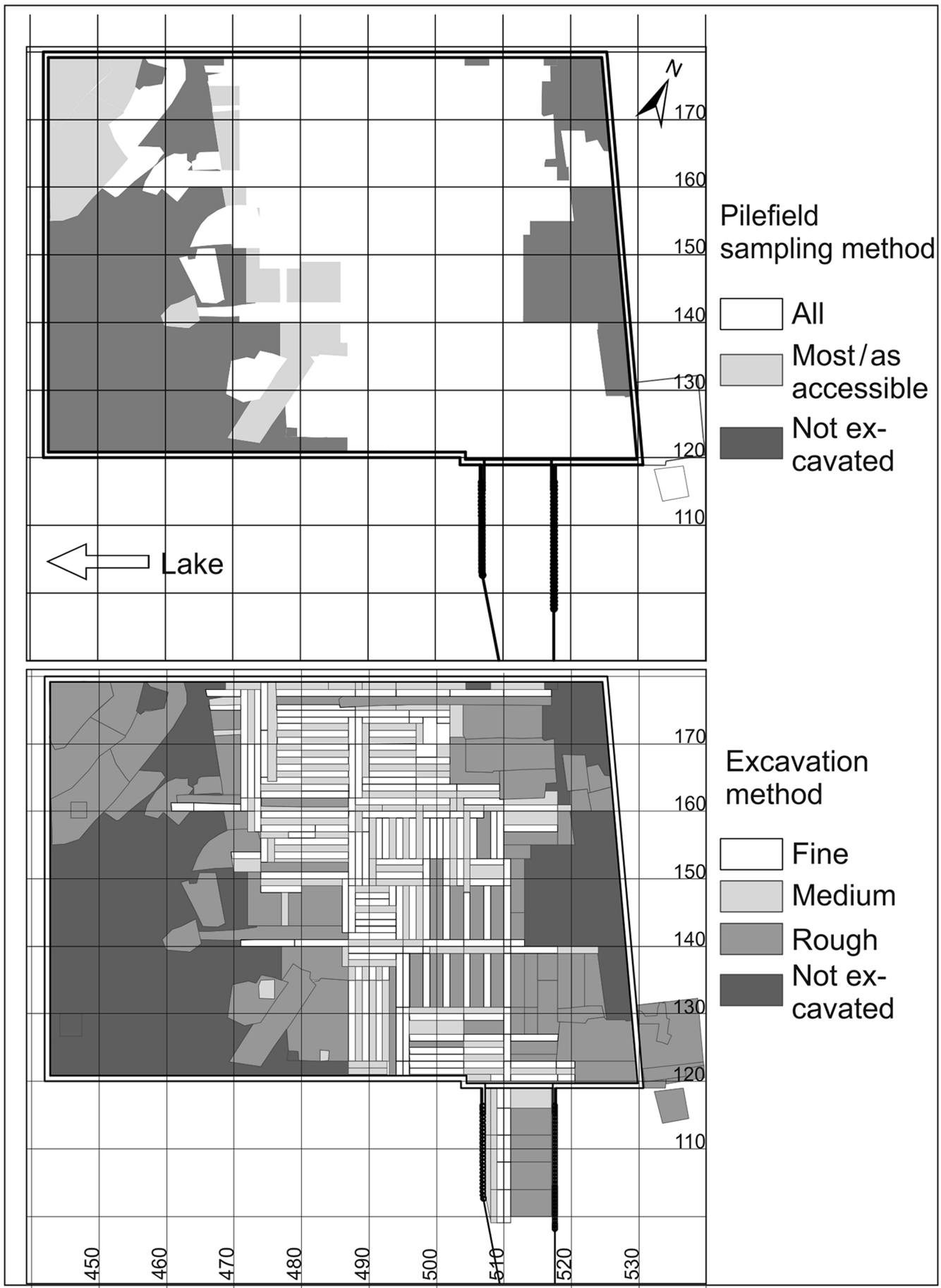

Figure 3. Map of the Parkhaus Opéra site, with the excavated areas and the methods of investigation. Grid numbers represent metres (figure by Niels Bleicher). 


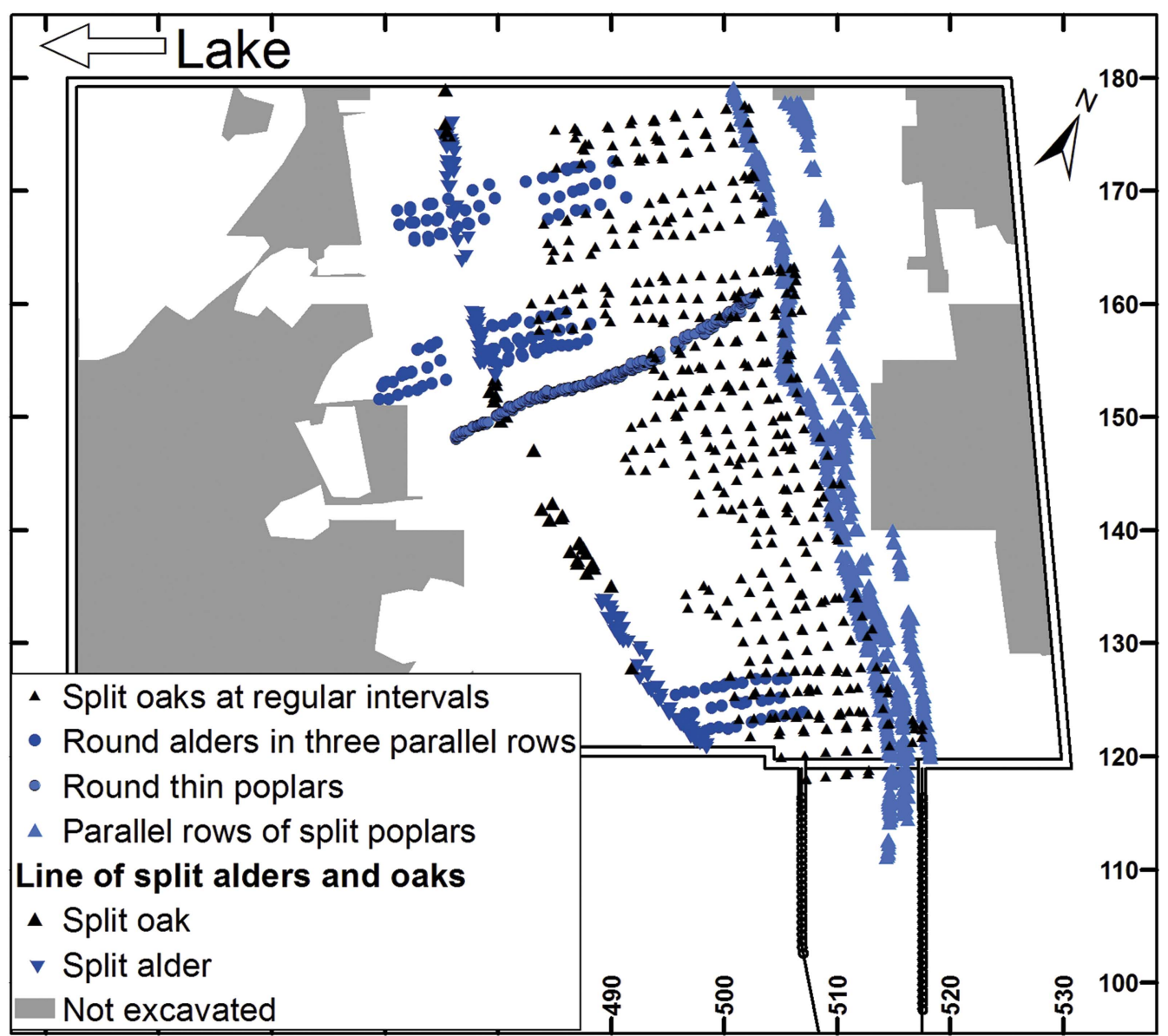

Figure 4. Examples of visually detectable structures by means of mapping piles grouped by species, size and crosssection (figure by Niels Bleicher).

The dendrochronological analyses followed a dendrotypological approach (Billamboz 2008: 147; Bleicher \& Burger 2015) that sorts the data into 'dendrogroups' according to species, number of rings, growth trend, cross-sections and anatomical anomalies. For illustration, several dendrogroups of the first settlement phase are shown in Figure 5. It shows that the tree-ring series can be subdivided into groups that share features, such as the number of rings and sudden growth reductions. This method aids the dating process, particularly of shorter series, and provides a basis for further ecological and economic analyses. In total, more than 2800 samples were analysed dendrochronologically, 2121 of which could be dated.

Dendrochronological dating of stratified horizontal timbers allows us to link dendrochronological phases with stratigraphic layers (Figures $2 \&$ S5). The results were verified by testing the spatial relationships between the dendrochronologically (and therefore independently) defined buildings and patches of loam identified within the layers. Such loam patches are regularly found in lakeside settlements, and their interpretation has been the (C) Antiquity Publications Ltd, 2018 


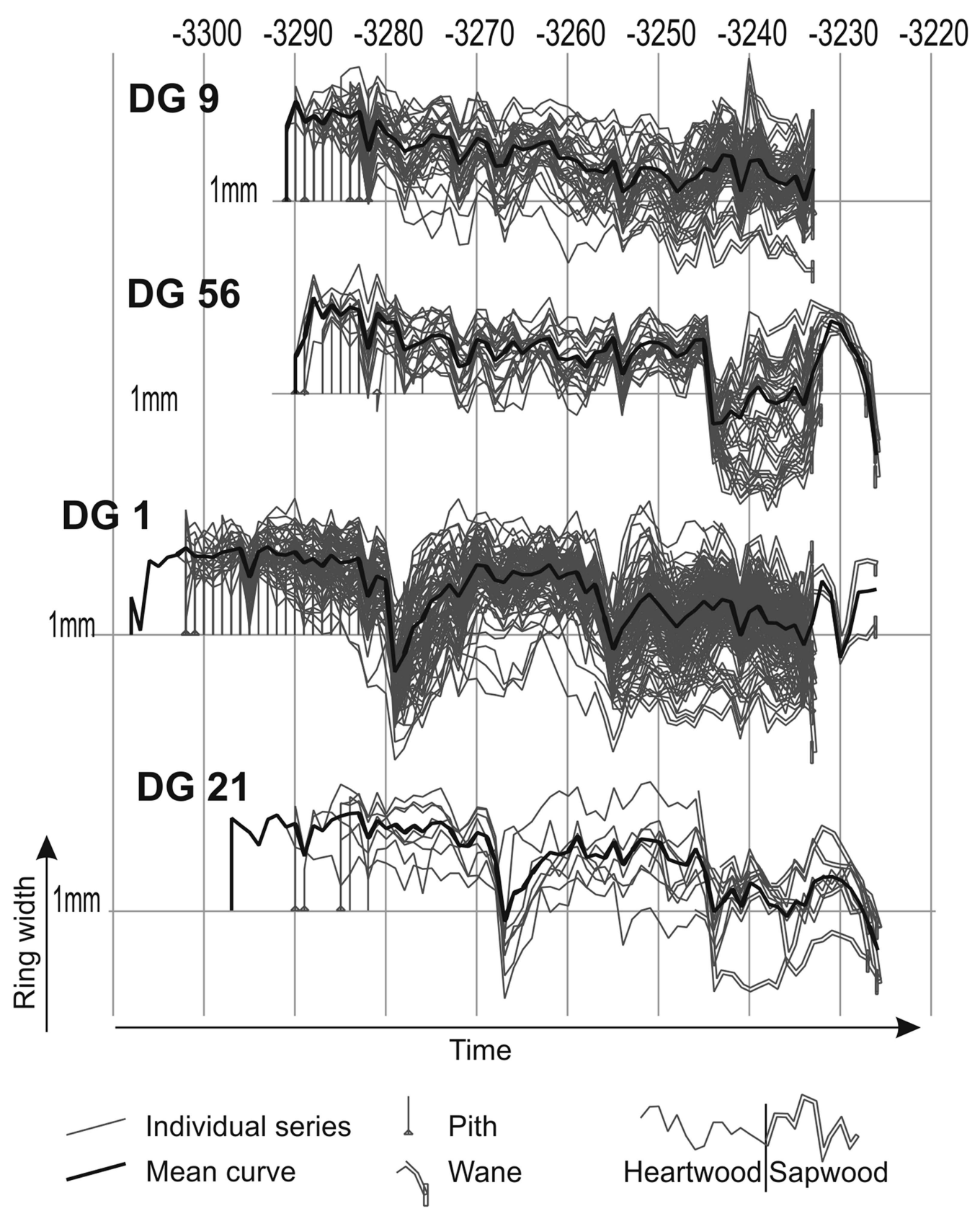

Figure 5. Examples of dendrogroups from phase 1 showing different timings of sudden growth reductions (figure by Niels Bleicher).

subject of a decade-long debate (Dieckmann et al. 2006: 211-19). The patches are usually a few square metres in size, and their outlines often show no signs of intentional design. At Parkhaus Opéra and other sites they regularly contain burnt loam fragments, show evidence of collapse and have multiple layers (Bleicher $e t$ al. 2018). We interpret these loam patches as 
the remains of hearths, which had periodically been deposited beneath the buildings during repair.

Analysis of the archaeological layers and their contents suggests that the settlement was built over shallow water (Bleicher \& Ruckstuhl 2015; Bleicher et al. 2018), which is confirmed by the palaeoecological analysis of the layer contents (e.g. Heiri et al. 2017). Loam patches were found mainly within the ground plans of houses, probably indicating the disposal of old hearth plates through an opening in the raised floor during regular repairs. Such floor openings are known from Horgen-period features at Seekirch-Stockwiesen (Germany, twenty-ninth century BC), and from Younger Neolithic Pfyn Culture features at Reute-Schorrenried (Germany, thirty-eighth century BC) and Thayngen-Weier (Switzerland) (Guyan 1968; Mainberger \& Billamboz 1998: 53; Schlichtherle 2004: 28, fig. 23; Bleicher 2009).

\section{Results}

We will focus on the settlement plans for phases 1, 3, 4 and 6, which belong to the Horgen Culture. Phase 2 was only marginally present in the excavated area, and phase 5 yielded timber that was hardly datable. The settlement plans for phases 7 and 8 (Corded Ware Culture) will be discussed elsewhere. For phase 1 (3234-3226 BC; layer 12), we have reconstructed 15 rectangular buildings, oriented with their shorter sides facing the lake and each closely associated with the loam patches in layer 12 (Figure 6: upper left). Several buildings to the north of structure 110 can be grouped into pairs of one large and one small building, some of which stood with the narrow sides facing each other, some side by side. The absence of an associated central loam patch and of any clear subdivision into bays suggests that structure 110 may represent a walkway; it bears similarities with a structure from phase 3 that we interpret as a footbridge (Figure 6: upper right, labelled with 'a'). Parallel rows of split poplar posts to the landward side, which had obvious spatial links with the buildings of phase 1 , indicate that a trackway or footbridge ran parallel to the lakeshore, providing access to the associated buildings. Indeed, in places, the trackway merges with the buildings, a phenomenon also observed at bog settlements in Upper Suabia (e.g. Schlichtherle 2004: fig. 18). This merging of trackway and buildings is particularly evident in structure 113 . The phase 1 settlement as a whole was separated from the open lake by a row of split alder piles; the curving line of this fence may indicate the presence of at most two further buildings, beyond the excavated area.

Phase 3 (3176-3153 BC; layer 13) comprises three rows of buildings. A double row of split poplar posts (Figure 6: upper right, labelled as 'e'), only a small part of which is in the excavated area, suggests that a trackway similar to that in phase 1 ran along the landward side of the settlement (Bleicher \& Burger 2015: 132). As in phase 1, many of the loam patches from layer 13 were located centrally in phase 3 buildings (Figure 6: upper right). The most spectacular find from layer 13 is a complete wooden door, made from poplar planks and two hazel lashes with ash wedges (Figure 7; Bleicher \& Ruckstuhl 2015: 76-78). An unusual feature of phase 3 is a fence of thin poplar posts, running north-east to south-west through the settlement, adjacent to the footbridge (Figure 6: upper right). The settlement may also have been subdivided a second time at 490/130m (between buildings 319 and 321), where

(C) Antiquity Publications Ltd, 2018 

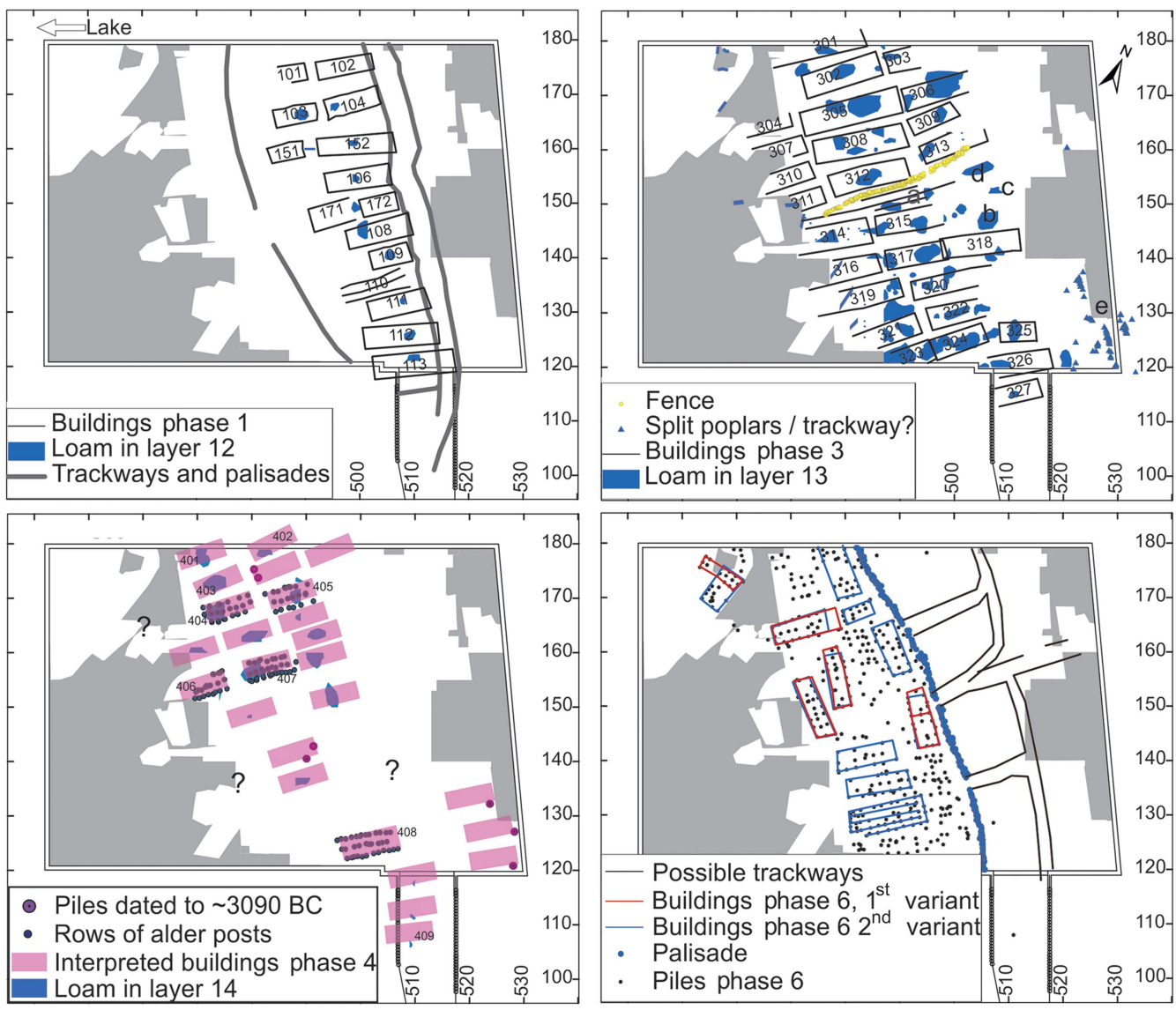

Figure 6. Settlement plans of phases 1, 3, 4 and 6 (figure by Niels Bleicher).

the distance between the buildings was unusually large. Although a small number of dated piles, loam patches and finds were found on the landward side of the houses (at around 505/ $150 \mathrm{~m})$, no obvious structures can be identified there.

We hypothesise that the phase 3 settlement was divided into four sectors (Figure 8). The finds from sectors A and C differ clearly from those found in sector B, the most notable difference being the absence of high-status perforated axes in the latter (Figure 9). Similarly, pendants made from bear fangs are present in sectors $\mathrm{A}, \mathrm{C}$ and $\mathrm{D}$, but not in $\mathrm{B}$, whereas dog-, wolf- and pig-tooth pendants are found across all sectors. Differential distribution patterns are also observed for raw materials and certain tools (Figures S11-12). Lastly, some finds, such as curved-mouth ceramic pots and antler sockets for stone blades, show distinct differences in distribution, with typologically older elements absent from sector B (Figure 9).

Phase 3 activity is divided into two: phase $3(3176-3160 \mathrm{BC})$ and phase $3 \mathrm{a}(3161-3153$ $\mathrm{BC}$ ). This is based on felling dates (Figure S4), which indicate that while repair work to most of the existing buildings ceased in $3160 \mathrm{BC}$, new buildings were erected from $3161 \mathrm{BC}$ onwards in the south-eastern area of the settlement (Figures $8 \&$ S14). Building 322 has an intermediary position between these two phases. 


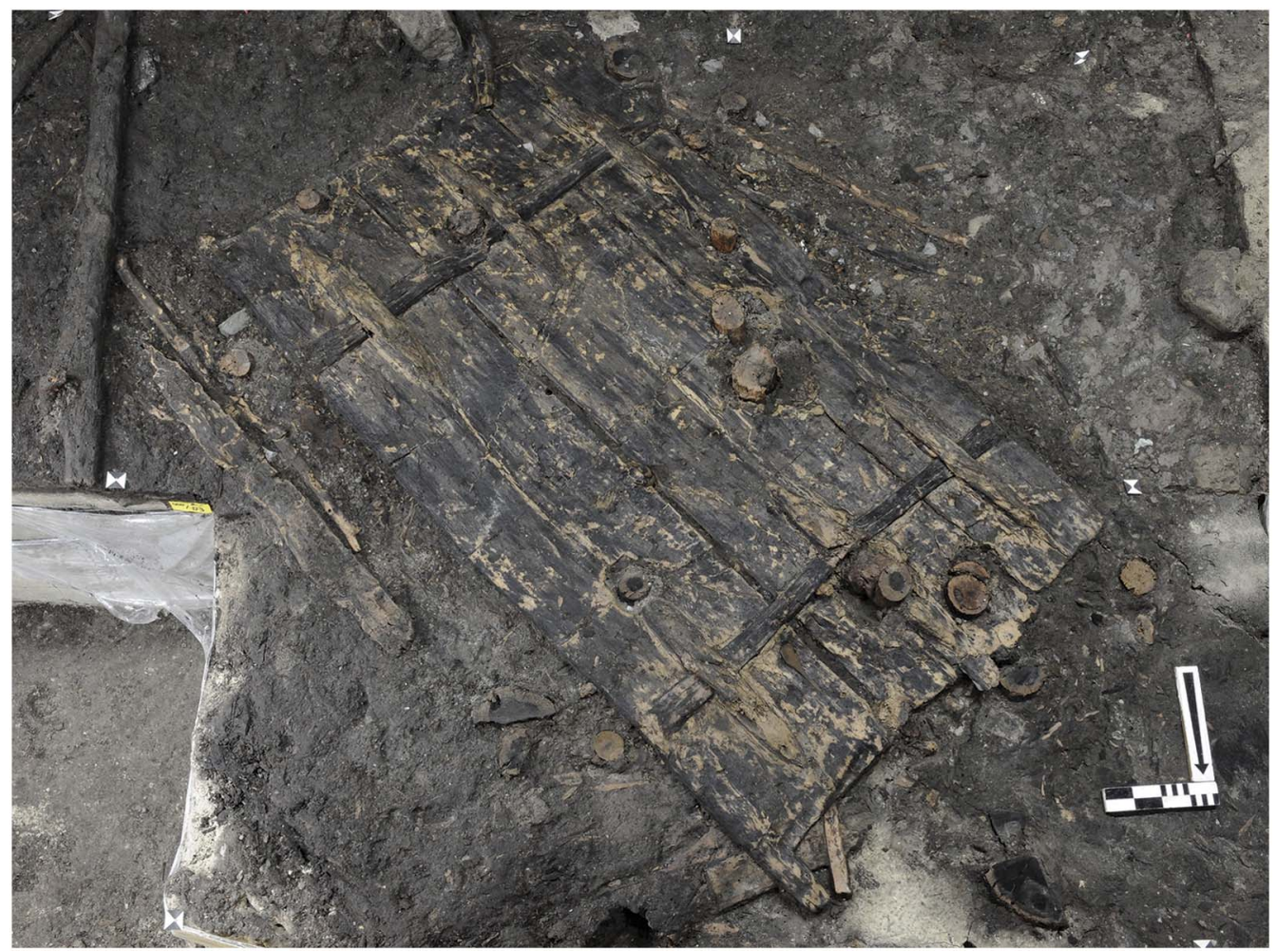

Figure 7. The wooden door during excavation (photograph courtesy of the Office for Urbanism, Zurich).

Phase 4 (c. 3090 BC; layer 14) is less well understood as a result of the widespread use of construction timbers that are not datable due to short tree-ring series. Several arrangements of alder posts, however, indicate buildings that correspond with loam features in layer 14 . On the assumption that the remaining loam patches in layer 14 would also have been associated with buildings (as they are in phases 1 and 3), it is possible to create an interpretative phase 4 settlement plan (Figure 6). The putative layout consists of at least three rows of rectangular buildings, oriented with their shorter end facing the lake. Their precise sizes, however, are unclear.

Phase 5 (c. 3060 BC; layer 15) cannot be reconstructed in detail, due to a lack of datable piles and discernible pile arrangements. Similarly, the settlement layout of phase 6 (28872885 BC; layer 16) is difficult to reconstruct, despite the presence of some dated piles (Figure 6). Nonetheless, although various construction scenarios are possible, the overall settlement layout certainly had changed by phase 6 (Figure 6). Several buildings now stood at different angles to each other on the lakeward side of a row of closely spaced poplar posts. Evidence also suggests that footbridges led from the buildings to the lakeshore in this phase (Bleicher \& Burger 2015: 134-35). 


\section{Discussion}

The close spatial association between loam patches and the ground plans of buildings in phases 1, 3 and 4 is interpreted as independent confirmation of the dendrochronological results obtained from the pile-field analysis. The resulting settlement reconstructions, however, can be extended. For layer 13 (phase 3), loam patches documented outside the regularly excavated area west of houses 301 and 302 suggest that the western row of buildings continued farther (Figure 6: upper right). Furthermore, in the centre of the excavated area, three loam patches are not linked to the ground-plan of any building (Figure 6: upper right, labelled as ' $b$ ', ' $c$ ' and ' $d$ '), although there are many undated piles in the vicinity. Two of these loam features ( $b$ and $c$ ) probably belonged to the same unidentified building, while the location of the third is in the line of the footbridge (labelled as 'a'), leading to an adjacent trackway. This loam might have been part of some type of entrance structure to the settlement. The tentative division of phase 3 (layer 13) into sectors is verified by the distribution of finds and raw materials (Harb et al. 2017: 257-62), and suggests that the sectors differed in status, raw material sources and activities. Woodworking, for example, was seemingly less important in sector B, suggesting instead the exchange of goods and artefacts. This may support the idea of complementarity of economic activities between different groups within the settlement. Although the phase 4 settlement layout cannot be reconstructed in detail, the distribution of the loam features suggests a similar alignment of buildings as in phase 3 (Figure 6). By phase 6, however, this had changed; houses were no longer organised in regular rows, representing a sharp break with the strictly defined layouts of previous phases.

The plans of the reconstructed buildings are defined by the positions of the wooden piles. It is probable, however, that these piles supported platforms on which the buildings were erected. These platforms then projected for technological reasons beyond the reconstructed ground plans and also beyond the footprints of the buildings constructed on top of these platforms. If an arbitrary $0.3-0.5 \mathrm{~m}$ is added, the projected gaps between the platforms within the sectors become very small; some may even have adjoined.

There are remarkable differences in the sizes of the building plans within phases 1 and 3 . Small variations in the floor space of houses are to be expected, but more substantial differences, with houses grouped into distinct size categories, are generally indicative of significant social or functional variation. Very small houses, for example, have been found at Bad Buchau-Torwiesen 2 (Germany), which is also a site of the Horgen Culture and dates to around $3260 \mathrm{BC}$ (Bleicher 2009); the presence of hearths and household refuse indicates that these were domestic spaces. Associated finds suggest that hunting played a more important role in the inhabitants' diets than it did for those living in large houses; this might reflect social differences (Schlichtherle et al. 2010). At the Parkhaus Opéra site, the floor plans in phases 1 and 3 range from $20-87 \mathrm{~m}^{2}$, but do not fall into distinct size classes (Table S1). As at Torwiesen 2, analysis of the faunal assemblages suggests that a higher proportion of game animals were consumed in smaller houses: 306, 309 and 326 (Schibler \& Schäfer 2017).

Sectors B and C were not fully excavated, but the building sizes appear comparable to those in sector A. The largest houses, however, were in sector $\mathrm{A}$. The sizes in phase 1 are also 
comparable. Here, however, the houses in the second row seem to be smaller than those in the first. Pairs of houses — one large and one small—were found to the north, but not to the south, of the footbridge.

The early thirty-fourth-century BC houses from Sutz-Lattrigen/Riedstation (Switzerland) also vary in size, within a similar range to those found in phases 1 and 3 at the Parkhaus Opéra site (Eberschweiler et al. 2006: 34). Again, pairs of houses—linked by footbridgeshave been found here, as in the Parkhaus Opéra phase 1, but the distances between the buildings are much bigger than at the Parkhaus Opéra site (Eberschweiler et al. 2006: fig. 12). Distinct categories of building size cannot be identified at either site.

A further question is whether there were open areas in front of the houses. Such 'front yards' have been found at Aichbühl (Germany, late fifth millennium BC) and at SeekirchStockwiesen (Germany, twenty-ninth century BC) (Schlichtherle 2004: 26, 47; Bleicher 2009). If the platform outlines corresponded to the walls, then it would have been difficult to move between the buildings, and there would be no shared external spaces for social interaction or for work requiring daylight. We therefore suggest that the houses were smaller than their platforms. Thus, where two rows of houses faced each other, the platforms and yards formed alleyways between and around them. This would explain how houses-such as building 305-that were surrounded on all sides by others, could be accessed. During phase 1 (c. $3230 \mathrm{BC})$, this function was fulfilled by a dedicated trackway.

In summary, the analyses carried out at the Parkhaus Opéra site show a number of interesting features. Phase 1 is a settlement with pairs of houses, as is also known from Sutz-Lattrigen/Riedstation. The floor plans in phase 3 varied considerably in size within each sector. The largest buildings were located in sector A. Furthermore, the distribution of finds indicates that sector B differed in several respects from A and C. No perforated axes were recovered from sector B, for example. Sector B's ceramics are typologically slightly 'younger' than those in sectors A and C, although they are all contemporaneous. A similar case is documented in Torwiesen 2 (Schlichtherle et al. 2010: 164). In a second feature common to these two sites, inhabitants of the smallest houses, when compared with those resident in the larger houses, show a slight preference for food acquired through hunting. As the finds assemblages from smaller houses also include some status symbols, however, house size does not necessarily equate to low status. Sectors A and B of phase 3 were separated by a fence, a rare example of a physical and symbolic division within a lakeside settlement.

\section{Parkhaus Opéra in context}

The phase 3 settlement comprised at least 22 buildings, a considerable increase compared with the 15 buildings of phase 1 . Does this represent an increase in the overall number of inhabitants or the nucleation of a previously dispersed population from the surrounding area? A comparison between the dendrochronologically dated construction phases at Parkhaus Opéra and those from nearby sites helps to address this question (Figure $1 \&$ Table 1).

Two unconfirmed dendrodates around $3235 \mathrm{BC}$ indicate that the settlement at ZurichBauschanze may have preceded or overlapped with Parkhaus Opéra phase 1 (3234-3226 (C) Antiquity Publications Ltd, 2018 
Table 1. The Late Neolithic settlement sites in Zurich and their occupation phases (table by Niels Bleicher).

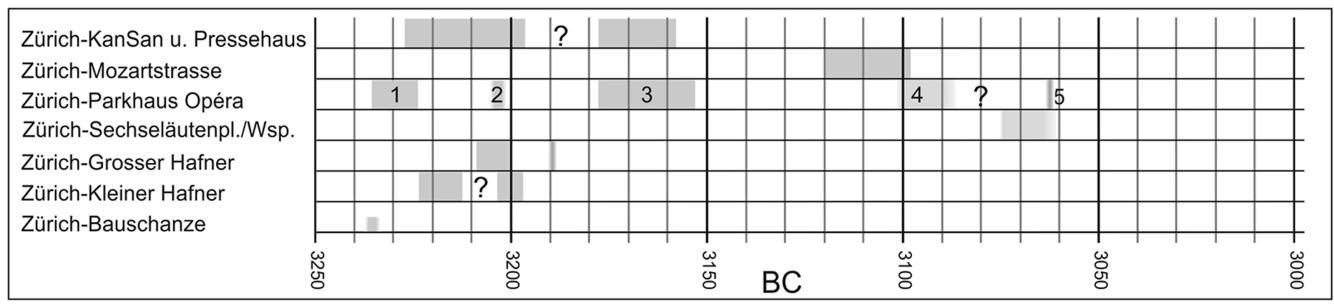

BC). The settlement at Zurich-Kanalisationssanierung Seefeld, starting in 3226 BC, seamlessly follows Parkhaus Opéra phase 1, and the site of Zurich-Kleiner Hafner was inhabited by $3222 \mathrm{BC}$ at the latest. In addition, the felling dates for Zurich-Grosser Hafner start only a few years after the final known felling dates for the Kleiner Hafner site. One might conclude that this reflected a sequence of settlements, if it were not for the contemporaneous felling dates of Zurich-Kanalisationssanierung Seefeld. These provide evidence of a settlement on the shoreline that existed for roughly 30 years or two shorter phases with a gap between 3220 and 3212 BC. At any rate, this settlement activity was synchronous with the other aforementioned sites (Table 1). The Horgen-period Zurich population did not migrate in a fixed monolithic group from one stretch of lakeshore to another. Rather, their movements included reorganisation. The varying house numbers in phases 1, 3 and 3a suggest that people who had lived together in one place could flexibly form new communities of different size, resulting in several contemporaneous sites visible from one another (Table1). As the number of buildings at most of these lakeside sites is unknown, however, it remains unclear whether the total local population changed over time.

Phase 4 at the Parkhaus Opéra site raises further questions. Just a few metres away is the Horgen-period layer 3 at Zurich-Mozartstrasse. The felling date of $3098 \mathrm{BC}$ has been identified at both sites, and the buildings at these two locations share the same orientation. Was Parkhaus Opéra phase 4 (c. 3090 BC) an independent phase or an extension of the slightly earlier settlement at Zurich-Mozartstrasse to the south? Or were the two settlements contemporaneous? Our archaeological concepts of the village or phase are too rigid in this regard; the felling dates of Parkhaus Opéra phase 4 follow on from those of Mozartstrasse layer 3 in a similar manner to which Parkhaus Opéra phase 3a succeeded phase 3 (above). If we abandon the notion of the village as the smallest settlement unit, we can instead focus on groups of buildings, which were relocated every 8-15 years within the immediate vicinity and combined to create new settlements. From this perspective, there is no reason to argue against the hypothesis of spatial and chronological continuity; such incremental transitions are not adequately described by creating distinct 'phases'. Nonetheless, this does not exclude the possibility of some chronologically well-defined and concerted construction activities, as shown by the beginning of Parkhaus Opéra phase 3, or by the big trackways along the shore. 

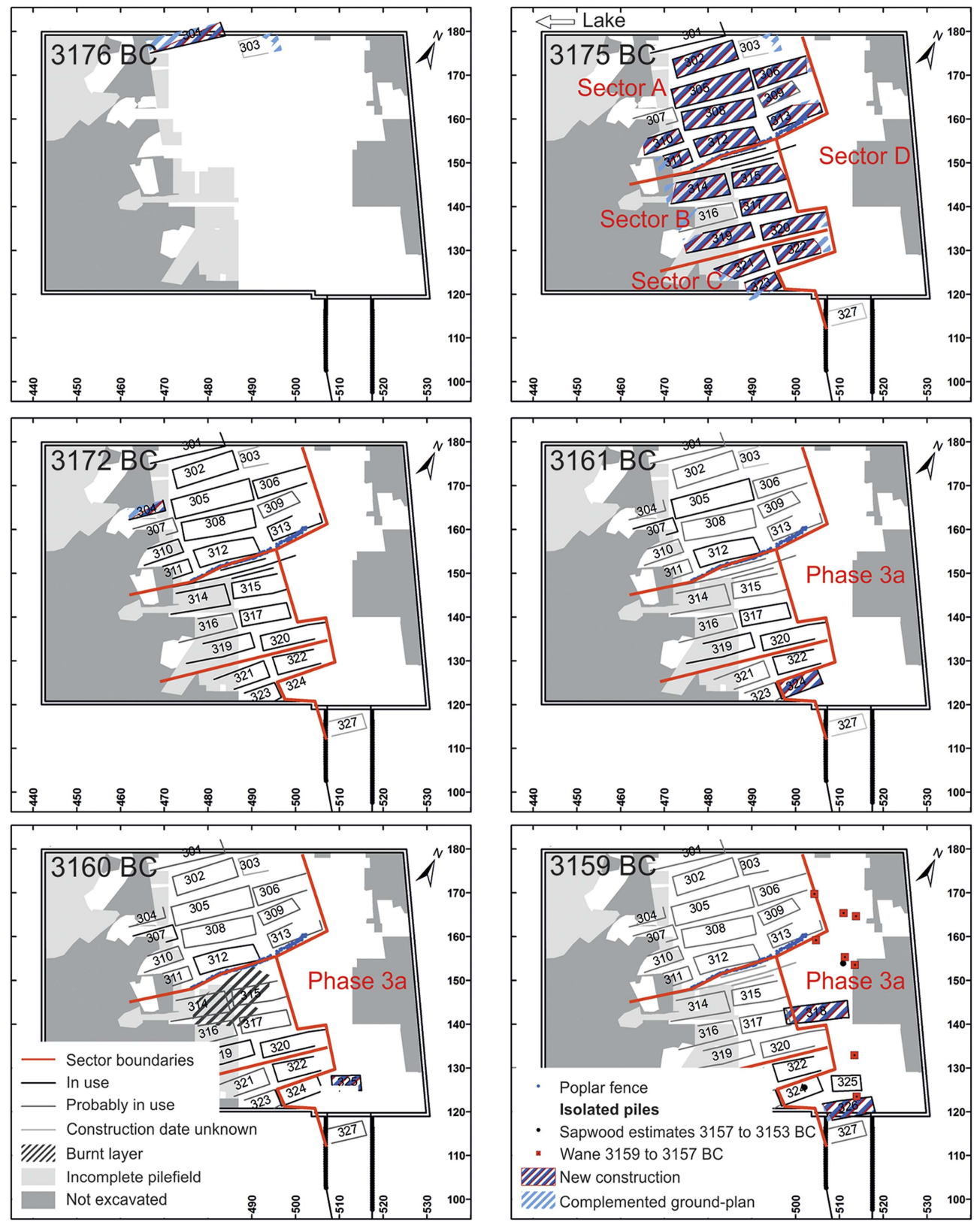

Figure 8. Annual building activity of phases 3 and 3a. The main building activity is in 3175 BC. The resulting settlement layout comprises four sectors (figure by Niels Bleicher).

\section{A regional comparison of village plans}

To develop a regional comparison for the period between 3400 and $2800 \mathrm{BC}$ requires a series of sufficiently well-researched settlement plans from other sites. These are to be found mainly

(C) Antiquity Publications Ltd, 2018 


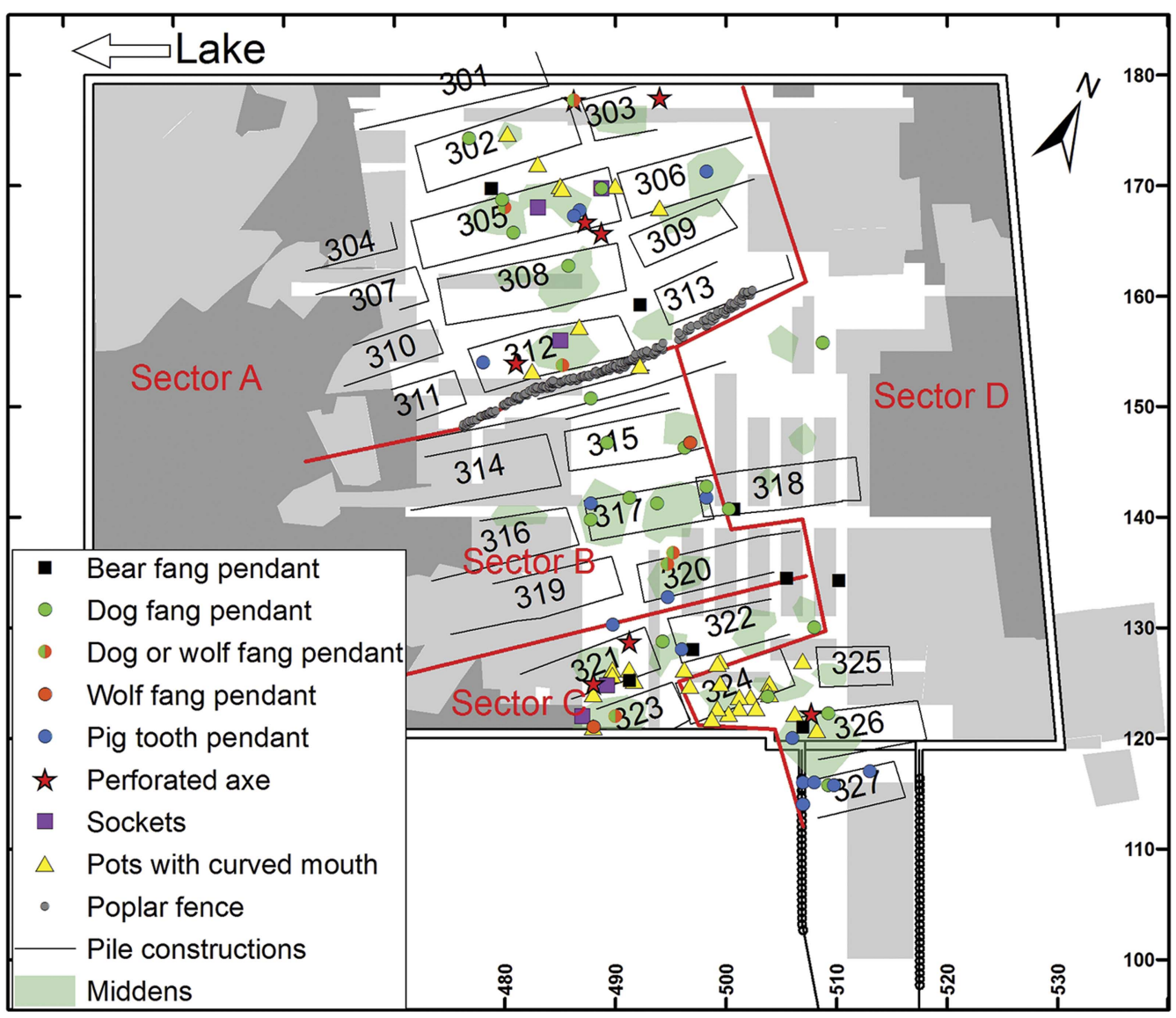

Figure 9. Map of status symbols, conservative elements and tooth pendants in layer 13 (figure by Niels Bleicher).

in the French Jura region, the Federsee bog in southern Germany, on Lake Bienne, at ArbonBleiche 3 on Lake Constance in Switzerland, and at Zurich-Mozartstrasse. Settlements in the French Jura region and the Federsee bog demonstrate layouts with a central axis and are known as "villages of the Seekirch type" (Schlichtherle 2004: 47). The main organisational feature that these Late Neolithic bogland sites share with contemporaneous settlements on the larger lakes, such as Arbon-Bleiche 3, Sutz-Lattrigen or Marin-les Piécettes, is the arrangement of their buildings into relatively clear rows (Leuzinger 2000; Honegger \& Michel 2002: fig. 9; Eberschweiler et al. 2006: fig. 13).

An overview of Circum-Alpine Neolithic settlement organisation reveals different regional traditions. There appears to be little or no relation between the timing of changes in settlements and the archaeological periods defined by ceramic typologies (Hofmann et al. 2016: fig. 8). Villages, where the buildings were arranged in two rows separated by a large gap, are known only from western Switzerland and date to between the thirty-sixth (Sutz-Lattrigen/Hauptstation) and the thirty-fourth (Sutz-Lattrigen/Riedstation) centuries BC. In eastern Switzerland and on Lake Constance, settlement development appears to have 


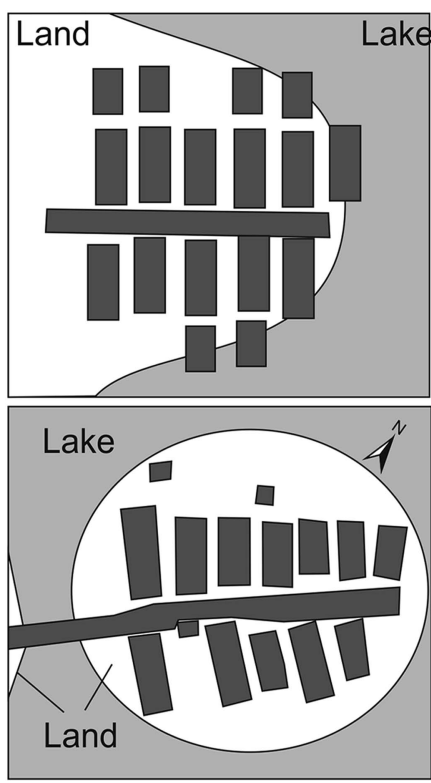

Chalain 3 II
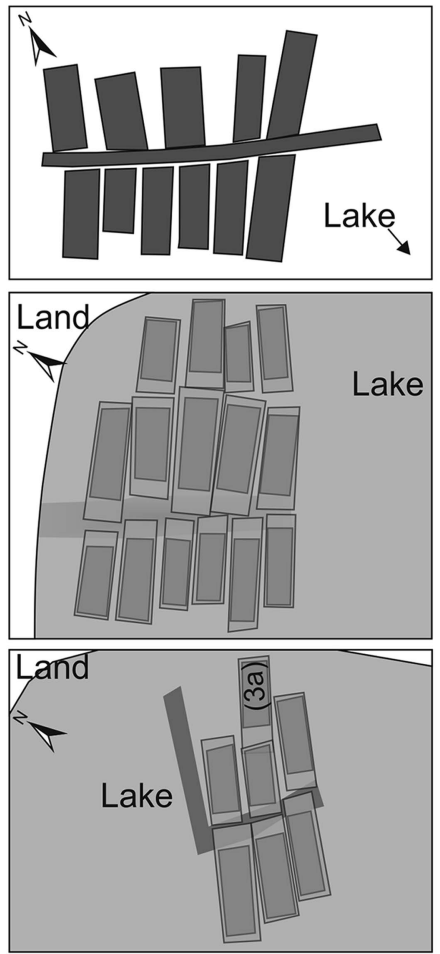

SeekirchStockwiesen

Parkhaus

Opéra

phase 3, sector $A$

Parkhaus

Opéra

phase 3,

sector $B$

Figure 10. Comparison of different Late Neolithic settlement structures with sectors $A$ and $B$ at Parkhaus Opéra, phase 3 (figure by Niels Bleicher).

plan of phase 3 at the Parkhaus Opéra site can be viewed as a combination of several groups of buildings, each of which had a similar structure to those observed at Seekirch-type

(C) Antiquity Publications Ltd, 2018 
settlements. This is relevant in that larger lakeside villages consisting of rows of houses may, in reality, comprise a cluster of house groups, each based on the organisational concept of the Seekirch type.

\section{Conclusion}

Our results suggest that a complex model of settlement development existed in the late fourth millennium BC between the French Jura region, southern Germany and around Lake Zurich. At the Parkhaus Opéra site, the settlement area was divided into groups of buildings, or sectors, which were separated, either by distance (possibly the measure was the length of a single step), or sometimes by a fence. Within each group, the buildings were oriented to maintain mobility and communication around the settlement. Smaller buildings often stood in a secondary row. The house groups or sectors are characterised by the variable quantities of status symbols recovered, indicating possible social differences. They also demonstrate evidence for different craft and work activities, indicating some economic complementarity. Differences in raw material distribution hint at individual networks and autonomy in the external contacts of households. Finally, differences in house size are linked to variation in ceramics and diet. At Torwiesen 2, the largest houses are associated with conservative-style ceramics. At Parkhaus Opéra, the sector with the largest houses (A) is also characterised by more conservative ceramics than the sector with few status symbols. At both Torwiesen 2 and Parkhaus Opéra, small houses and houses in the second row also have higher proportions of game animals in their faunal assemblages. Horgen-period society, therefore, demonstrates various social differences expressed through the spatial organisation of settlement and activities.

Late Neolithic settlements were relatively short-lived, existing for a period of only 8-15 years (Bleicher 2009). Interestingly, people sometimes returned to occupy the former sites and even individual house-places. At Gachnang-Niederwil (Switzerland), a building was repeatedly re-erected, as established by dendrochronological dating of the floor boards (Ebersbach 2009). At Torwiesen 2, the largest house with the highest-status materials also featured ceramics that were, by this time, already old-fashioned. At Parkhaus Opéra phase 3, the distribution of status symbols is the same as that of conservative ceramic typological elements, and both frequently occur in the sector with the largest houses. Combined, this information suggests that higher rank was linked to some type of tradition or lineage. These communities may, therefore, have developed incipient heritable socio-political roles. The evidence from the Parkhaus Opéra site suggests that the settlement pattern within a microregion, such as the eastern lakeshore of lower Lake Zurich, was divided into a multitude of contemporaneous and consecutive individual structures, whose size and shape fluctuated considerably as a result of ongoing reorganisation.

Despite these constant changes, status symbols were not concentrated in individual houses, but rather show meaningful distribution patterns at the level of house groups. It therefore appears that status did not belong exclusively to individuals, but rather to group members. Status may then have been transferred, over time, to new group members or generations. These were therefore were probably stable units within a highly dynamic settlement system. Such an interpretation challenges the concept that Late Neolithic societies 
in the northern Alpine foreland adhered to a non-correspondence settlement system. The strictness of settlement layout and the lack of status symbols across entire sectors imply a high level of social control. Hanson and Hillier (1987: 265) described their non-correspondence system as a means to generate encounters and ties between people who do not belong to the same group. Parkhaus Opéra, however, provides evidence of a means to regulate contact between people through boundaries such as fences-the opposite of a non-correspondence system. Strong similarities between the layouts at different Late Neolithic settlements indicate an identical overall concept of social space.

Rather than arguing that societies adopt either a correspondence or a non-correspondence system, Hanson and Hillier (1987) talked about the extent to which any given society adopted either system and the conditions under which such systems develop. They cite Levi-Strauss (1972: 292) who warned that sometimes "spatial configuration reflects not the true, unconscious social organisation but a model existing consciously in the native mind, though its nature is entirely illusory and even contradictory to reality". This reminds us that we cannot directly reconstruct the true social organisation of Late Neolithic (lakeshore) settlements. The importance of our study is that it provides evidence of a spatial system repeatedly applied and probably of the outcome of the participants' own social narrative. Furthermore, it bears surprisingly strong traces of social categorisation and control, while remaining highly mobile and flexible. The precise dating and the large quantities of organic materials from the Zurich area promise the opportunity for further study of the conditions under which this system developed during the Neolithic period.

\section{Supplementary material}

To view supplementary material for this article, please visit https://doi.org/10.15184/aqy.2018.109

\section{References}

Billamboz, A. 2006. Dendroarchäologische Untersuchungen in den neolithischen Ufersiedlungen von Hornstaad-Hörnle, in Regierungspräsidium Stuttgart—Landesamt für Denkmalpflege (ed.) Siedlungsarchäologie im Alpenvorland IX. Forschungen und Berichte zur Vor-und Frühgeschichte in Baden-Württemberg, Band 98: 297-414. Stuttgart: Konrad Theiss.

- 2008. Dealing with heteroconnections and short tree-ring series at different levels of dating in the dendrochronology of the southwest German pile-dwellings. Dendrochronologia 26: 145-55. https://doi.org/10.1016/j.dendro.2008.07.001

Bleicher, N. 2009. Altes Holz in neuem Licht. Archäologische und dendrochronologische Untersuchungen an spätneolithischen Feuchtbodensiedlungen in Oberschwaben. Stuttgart: Konrad Theiss.
Bleicher, N. \& M. Burger. 2015.

Dendroarchäologie und Pfahlfeldanalyse, in

C. Harb \& N. Bleicher (ed.) Zürich-Parkhaus Opéra. Eine neolithische Feuchtbodenfundstelle. Band 1. Befunde, Schichten und Dendroarchäologie: 100-42. Zurich: FO-Publishing.

Bleicher, N. \& C. Harb (ed.). 2015. ZürichParkhaus Opéra. Eine neolithische Feuchtbodenfundstelle. Band 1. Befunde, Schichten und Dendroarchäologie. Zurich: FO-Publishing.

- 2017. Zürich-Parkhaus Opéra. Eine neolithische Feuchtbodenfundstelle. Band 3:

Naturwissenschaftliche Analysen und Synthese. Zurich: FO-Publishing.

Bleicher, N. \& B. Ruckstuhl. 2015. Die archäologischen Befunde, in N. Bleicher \& C. Harb (ed.) Zürich-Parkhaus Opéra. Eine neolithische Feuchtbodenfundstelle. Band 1. Befunde, Schichten und Dendroarchäologie: 50-99. Zurich: FO-Publishing. 
Bleicher, N., F. Antolín, O. Heiri, S. Häberle, H. Hüster Plogmann, S. Jacomet, C. Pümpin, P. Rentzel, M. Schäfer, J. Schibler, P. Wiemann, M. van Hardenbroek, M. Tóth $\&$ N. ZwEIFEL. 2018. Middens, currents and shorelines: complex depositional processes of waterlogged prehistoric lakeside settlements based on the example of Zurich-Parkhaus Opéra (Switzerland). Journal of Archaeological Science 97: 26-41.

https://doi.org/10.1016/j.jas.2018.06.010

Dieckmann, B., A. Harwath \& J. Hoffstadt. 2006. Hornstaad-Hörnle IA. Die Befunde einer jungneolithischen Pfahlbausiedlung am westlichen Bodensee, in Regierungspräsidium Stuttgart—Landesamt für Denkmalpflege (ed.) Siedlungsarchäologie im Alpenvorland IX. Forschungen und Berichte zur Vor- und Frühgeschichte in Baden-Wïttemberg, Band 98: 8-276. Stuttgart: Konrad Theiss.

Doppler, T., B. Pollmann, S. Pichler, S. Jacomet, J. Schibler \& B. Röder. 2011. Bauern, Fischerinnen und Jäger: Unterschiedliche Ressourcen und Landschaftsnutzung in der neolithischen Siedlung Arbon Bleiche 3 (Thurgau, Schweiz)?, in J. Studer, M. David-Elbiali \& M. Besse (ed.) Paysage ... L'impact des activités humaines sur l'environnement du Paléolithique à la période romaine. Cahiers d'archéologie romande 120: 143-58. Lausanne: Musée cantonal d'archéologie et d'histoire.

EвERSBACh, R. 2009. Gachnang-Niederwil TG-Egelsee: Neuinterpretation der Baubefunde. Jahrbuch Archäologie Schweiz 92: 97-116.

- 2010. Soziale Einheiten zwischen 'Haus' und

'Dorf - neue Erkenntnisse aus den Seeufersiedlungen, in E. Classen, Th. Doppler \& B. Ramminger (ed.) Familie - VerwandtschaftSozialstrukturen: Sozialarchäologische Forschungen zu neolithischen Befunden. Fokus Jungsteinzeit. Berichte der AG Neolithikum. Band 1: 141-56. Kerpen-Loogh: Welt und Erde.

Eberschweiler, B., A. Hafner \& C. Wolf. 2006. Unterwasserarchäologie in der Schweiz. Bilanz und Perspektive aus den letzten 25 Jahren, in A. Hafner, U. Niffeler \& U. Ruoff (ed.) The new view: underwater archaeology and the historical picture. Proceedings of the $2^{\text {nd }}$ International Congress on Underwater Archaeology: 24-46. Basel: Archäologie Schweiz.
GuYan, W.U. 1968. Die jungsteinzeitlichen Dörfer im Weier bei Thayngen. Zeitschrift Schweizer Archäologie und Kunstgeschichte 25: 1-37.

Hanson, J. \& B. Hillier. 1987. The architecture of community: some new proposals on the social consequences of architectural and planning decisions. Architecture and Behaviour 3: 251-73.

Harb, C. \& N. Bleicher (ed.). 2016. ZurichParkhaus Opéra. Eine neolithische Feuchtbodenfundstelle. Band 2, Funde. Zurich: FO-Publishing.

Harb, C., N. Bleicher, E. Jochum-Zimmermann, A. Kienholz, B. Ruckstuhl \& M. Weber. 2017. Mensch und Gesellschaft, in N. Bleicher \& C. Harb (ed.) Zürich-Parkhaus Opéra. Eine neolithische Feuchtbodenfundstelle. Band 3: Naturwissenschaftliche Analysen und Synthese: 246-62. Zurich: FO-Publishing.

Hasenfratz, A. \& E. Gross-Klee. 1995. Siedlungswesen und Hausbau, in W.E. Stöckli, U. Niffeler \& E. Gross-Klee (ed.) Die Schweiz von Paläolithikum bis zum frühen Mittelalter. Neolithikum: 195-230. Basel: Schweizerische Gesellschaft für Ur- und Frühgeschichte.

Heiri, O., M. Tóth, M. van Haardenbroek \& N. ZweIFel. 2017. Chironomiden- und Cladocerenfossilien, in N. Bleicher \& C. Harb (ed.) Zürich-Parkhaus Opéra. Eine neolithische Feuchtbodenfundstelle. Band 3:

Naturwissenschaftliche Analysen und Synthese: 30-50. Zurich: FO-Publishing.

Hofmann, D., R. Ebersbach, T. Doppler \& A. Whittle. 2016. The life and times of the house. Multi-scalar perspectives on settlement from the Neolithic of the northern alpine foreland. European Journal of Archaeology 19: 596-630. https://doi.org/10.1080/14619571.2016.1147317

Honegger, M. \& R. Michel. 2002. Neue Aspekte der Cortaillod-Kultur im Neuenburgerland. Archäologie Schweiz 25: 31-39.

KaESer, M.-A. 2004. Les lacustres: Archéologie et mythe national. Le savoir suisse 14. Lausanne: Presses Polytechniques Universitaires Romandes.

LeuZinger, U. 2000. Die jungsteinzeitliche Seeufersiedlung Arbon-Bleiche 3: Band 1, Befunde. Frauenfeld: Departement für Erziehung und Kultur des Kantons Thurgau.

LeVi-Strauss, C. 1972. Structural anthropology one. Harmondsworth: Penguin. 
Mainberger, M. \& A. Billamboz. 1998. Das Moordorf von Reute. Breisgau: Teraqua CAP. Schibler, J. \& M. Schärer. 2017. Von Hand aufgelesene Tierknochen, in N. Bleicher \& C. Harb (ed.) Zürich-Parkhaus Opéra. Eine neolithische Feuchtbodenfundstelle. Band 3: Naturwissenschaftliche Analysen und Synthese: 92-127. Zurich: FO-Publishing.

Schlichtherle, H. 2004. Grosse Häuser-kleine

Häuser. Archäologische Befunde zum Siedlungswandel am neolithischen Federsee, in Landesdenkmalamt Baden-Württemberg (ed.) Ökonomischer und ökologischer Wandel am vorgeschichtlichen Federsee. Archäologische und naturwissenschaftliche Untersuchungen: 13-55. Freiburg im Breisgau: Janus.

Schlichtherle, H., N. Bleicher, A. Dufraisse, P. Kieselbach, U. Maier,

E. Schmidt, E. Stephan \& R. Vogt. 2010. Baustrukturen und Siedlungsabfälle als Indizien der Sozialstruktur und Wirtschaftsweise einer endneolithischen Siedlung am Federsee, in E. Classen, T. Doppler \& B. Ramminger (ed.) Familie—Verwandtschaft—Sozialstrukturen: Sozialarchäologische Forschungen zu neolithischen Befunden: 157-78. Loogh: Welt und Erde.

Received: 17 November 2017; Revised: 8 February 2018; Accepted: 19 February 2018

(C) Antiquity Publications Ltd, 2018 